\title{
Origin of Inferior Phrenic Arteries in the Celiac Trunk
}

\author{
Origen de las Arterias Frénicas Inferiores en el Tronco Celíaco \\ "Selma Petrella; ** Celio Fernando de Sousa Rodriguez; ${ }^{* * *}$ Emerson Alexandre Sgrott; \\ ***** Geraldo José Medeiros Fernandes; ${ }^{* * * *}$ Sergio Ricardo Marques; ***** José Carlos Prates
}

PETRELLA, S.; RODRIGUES, C. F. S.; SGROTT, E. A; FERNANDEZ. G. J. M.; MARQUES, S. R. \& PRATES. J. C. Origin of inferior phrenic arteries in the celiac trunk. Int. J. Morphol., 24(2):275-278, 2006.

SUMMARY: The knowledge of the arterial anatomic variations is very important for the clinical, radiological and surgical diagnosis. Regarding inferior phrenic arteries, which irrigate the diaphragm, it is known that they vary in relation to their origin. The purpose of the present study is to verify these variations. The abdominal cavity of eighty-nine adult cadavers of both sexes was dissected, of which 69 fixed in 10\% formalin solution and 20 non-fixed. The fixed cadavers were dissected in Laboratories of Anatomy of the Federal University of São Paulo (UNIFESP-EPM), the Santo Amaro University (UNISA) and Lusiadas de Santos University (UNILUS). The nonfixed cadavers were dissected from the Death Verification Service of the city of São Paulo (USP) and from the UNIFESP Brazil. After exposure of the celiac axis, we analyzed the possible emission of inferior phrenic arteries from this vessel as well as site of origin. The results showed us the presence of inferior phrenic arteries in 31 (34.83\%) among the 89 cadavers. In the remained $58(65.17 \%)$, the celiac trunkhad not these branches. It was observed that in $19(21.35 \%)$ out of the 89 cadavers the inferior phrenic artery originating at the left contour of the celiac axis, in five (5.62\%) cadavers, the phrenic artery presented its origin at the right contour and seven (7.86\%) presented two phrenic arteries of which five were independently originated from each side of the celiac trunk and two (2.25\%) from one axis.

KEY WORDS: Anatomy; Phrenic artery; Celiac artery; Anatomical variation.

\section{INTRODUCTION}

Vascular variations are constantly observed in dissection of adult cadavers (Lipshutz, 1917).

The phrenic arteries as collateral branches in the aorta abdominal part had their origin in right and/or left anterior contour of this vessel (Anson \& McVay, 1936), but it may also occur as branches originated directly from the celiac trunk, independently at the right and/or left sides or from a common trunk (Lipshutz).

In general, these accessory vessels, which supply the diaphragm, are of small caliber (Lipshutz; Michels, 1951; 1953b).

The purpose of this study was to analyze percentage of inferior phrenic arteries originating at the celiac trunk either in males or females, as well as the percentage of origin of these arteries in the left and/or right sides of the celiac trunk.

\section{MATERIAL AND METHOD}

Eighty-nine cadavers from the following Institutions were dissected: Death Verification Service of the Federal University of São Paulo (UNIFESP/EPM), Obituary Service of the city of São Paulo at the Medical University of São Paulo (USP) and Anatomy Laboratories of the Federal University of São Paulo (UNIFESP/EPM), Medical Sciences Faculty of the Lusíada University Center (UNILUS) and the Santo Amaro University (UNISA).

Sixty-nine cadavers were dissected and fixed in $10 \%$ formalin solution, their ages ranging from 21 to 82 years, of which 60 were males and 9 females.

Also, 20 non-fixed cadavers were dissected and maintained in a frigorific chamber, of which 12 were males and eight females, with ages ranging from 34 to 88 years. Dissections were performed during the necropsies in the following institutions: Death Verification Service of the city

* Arbovirus Division, Adolfo Lutz Institute, São Paulo, Brazil.

** Department of Morphology, Federal University of Alagoas, Brazil.

*** Descriptive and Topographic Anatomy Division, Vale do Itajaí University, Santa Catarina, Brazil.

${ }^{* * * *}$ Descriptive and Topographic Anatomy Division, Federal University of São Paulo, Brazil. 
of São Paulo in the Medical Faculty of the São Paulo University and in the Death Verification Service of the Federal University of São Paulo

To dissect the celiac trunk in the fixed cadavers, pancreas was removed and its body sectioned or divided with the aid of scissor. In non-fixed cadavers, the celiac trunkwas reached by the omentum, opening the flaccid part of the lesser omentum. Ganglions and the nervous tissue of the celiac plexus, involving the initial segment of the celiac trunk, were withdrawn with the aid of a pincer and scissor to allow observing disposition of these inferior phrenic arteries at the celiac trunk.

After resection of subjacent tissues to the diaphragmatic crura and adhesion of tissues all along the median arcuate ligament, these structures were exposed allowing observation of its relationships with the celiac trunk.

Statistical Analysis (Siegel et al., 1976). To study the possible associations between sexes and the presence of inferior phrenic arteries at the celiac trunk, in a type $2 \mathrm{x}$ 2 table, the Chi-square test for two independent samples was used.

The rejection level for the null hypothesis was fixed in a value smaller or equal to $0.05 \%(5 \%)$. When the calculated statistics did not present significance, NS was used to characterize it.

\section{RESULTS}

The results of the presence of inferior phrenic arteries in the celiac trunk, when compared between sexes, in 89 cadavers, are shown in the Table I.

Table I The presence of the inferior phrenic arteries (IPAs) in the celiac trunk(CA) in cadavers according to gender and statistical result.

\begin{tabular}{lccc}
\hline & \multicolumn{2}{c}{ Gender } \\
\cline { 2 - 3 } Presence & Male & Female & Total \\
\hline CA with IPAs & 26 & 5 & 31 \\
CA with IPAs & 46 & 12 & 58 \\
\hline Total & 72 & 17 & 89 \\
\hline
\end{tabular}

$\mathrm{X}^{2}$ calc $=0.272 \mathrm{NS}$
Analysis of these results showed that the difference between sexes, in relation the presence of these structures was not statistically significantly.

In the cases where the celiac trunkhad no inferior phrenic arteries, no statistically significant difference between sexes was observed.

In 31 (34.83\%) cadavers, the inferior phrenic arteries had their origin in the celiac trunk (Fig. 1), in contrast to what occurred when evaluating 58 cadavers $(65.17 \%)$, in which the celiac trunk did show this collateral branch.

When the presence of the inferior phrenic arteries was analyzed in 31 cadavers, it was observed that 19 $(61.29 \%)$ or $21.35 \%$ of the overall cadavers analyzed in the current study, presented a left phrenic artery (Fig.2) with its origin at the left contour of the celiac trunk, 5 $(16.13 \%)$ or $5.62 \%$ of the total showing a right phrenic artery (Fig.3) with origin at the contour of right celiac trunk and $7(22.58 \%)$ or $7.86 \%$ of total, both arteries of which 5 (16.13\%) or $5.62 \%$ of the total had their origin independent of each side of the celiac trunk and in $2(6.45 \%)$ or $2.25 \%$ of the total from one celiac trunk.

\section{DISCUSSION}

In our study, we observed that the inferior phrenic arteries might have their origin either side of the celiac trunk or in booth sides, in different ratios.

The presence of these arteries in the celiac trunk was observed in $31(34.83 \%)$ of the 89 analyzed cadavers and the absence in 58 (65.17\%) (Fig.1). These results led us to conclude that the phrenic arteries with presence in the celiac trunk are a type of variation.

These findings are not in accordance with Michels (1953a), who reported this finding 74\% in 200 cadavers.

The phrenic origin in the left contour of the celiac trunk was observed in 19 (21.35\%) of the 89 cadavers, similar to the results of Pick \& Anson (1940), who reported to have found 34 (17\%) out of 200 cadavers and it is not in accordance with Lipshutz who observed six (7.23\%). On the other hand, in five cadavers we could observe one inferior phrenic artery, originating from the right contour of the celiac trunk, similar to those found by Lipshutz in three (3.61\%) cases.

The two inferior phrenic arteries origining in the celiac trunk, as independent branches, were found in five 

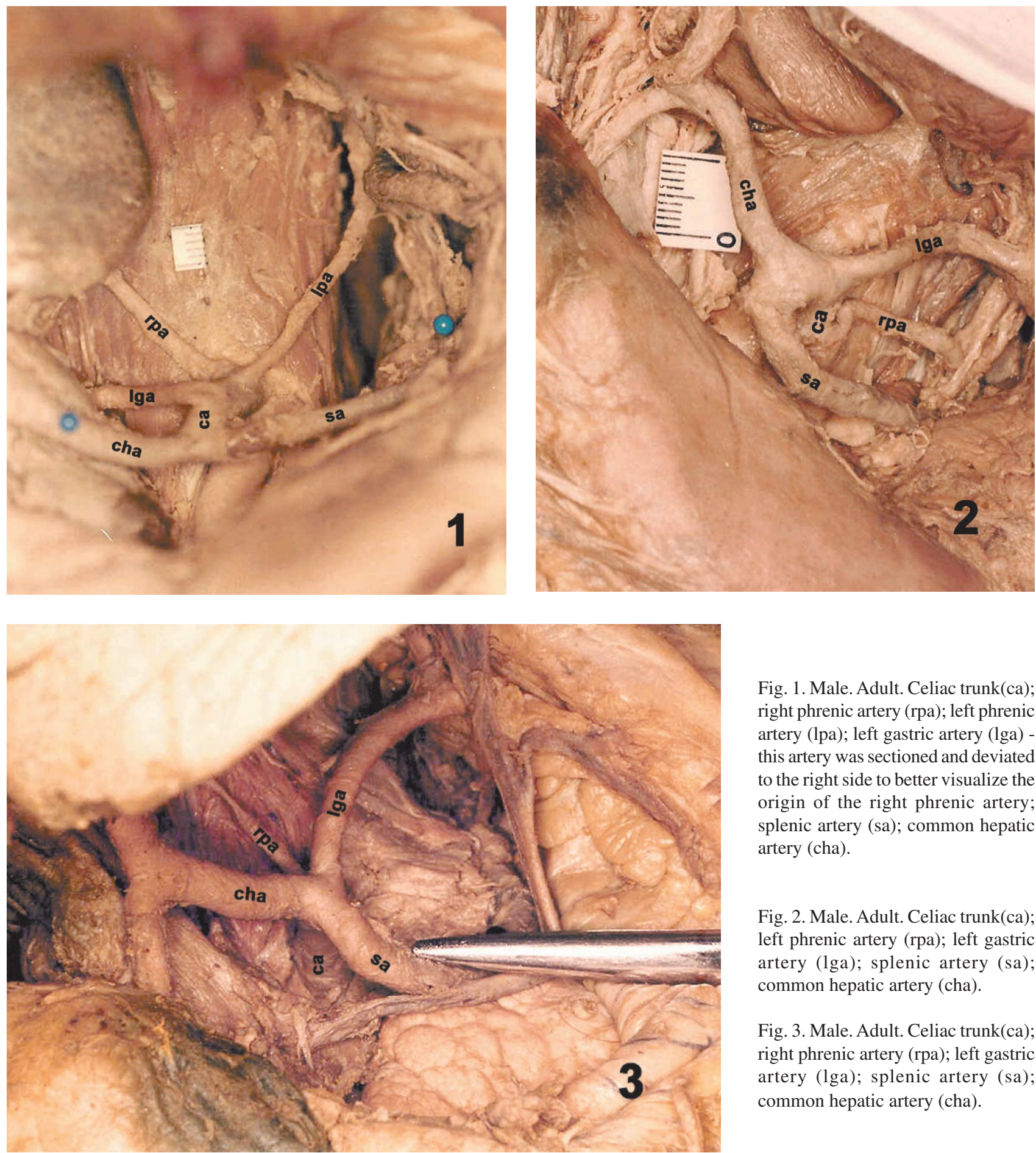

Fig. 1. Male. Adult. Celiac trunk(ca); right phrenic artery (rpa); left phrenic artery (lpa); left gastric artery (lga) this artery was sectioned and deviated to the right side to better visualize the origin of the right phrenic artery; splenic artery (sa); common hepatic artery (cha).

Fig. 2. Male. Adult. Celiac trunk(ca); left phrenic artery (rpa); left gastric artery (lga); splenic artery (sa); common hepatic artery (cha).

Fig. 3. Male. Adult. Celiac trunk(ca); right phrenic artery (rpa); left gastric artery (lga); splenic artery (sa); common hepatic artery (cha).

(5.62\%) cadavers, differing from Pick \& Anson who reported $41(20.5 \%)$ and are in agreement with Lipshutz, who observed five $(6.02 \%)$. The common trunk found in two $(2.25 \%)$ was similar to the percentage of $2.41 \%$ of Lisphutz and differing from the 25 (12.5\%) found by Pick \& Anson.
The knowledge of this type of variation shows that surgeons must be cautious to avoid unintentional sectioning of small caliper arteries, as it may occur during the celiac artery decompression in the compression syndrome of the celiac trunkby the median arcuate ligament. 
PETRELla, S.; RODRIGUES, C. F. S.; SGROTT, E. A; FERNANDEZ. G. J. M.; MARQUES, S. R. \& PRATES. J. C. Origen de las arterias frénicas inferiores en el tronco celíaco. Int. J. Morphol., 24(2):137-142, 2006.

RESUMEN: El conocimiento de las variaciones anatómicas arteriales es de gran importancia para los diagnósticos clínico, radiológico y quirúrgico. Con relación a las arterias frénicas inferiores que irrigan el diafragma, se tiene conocimiento que éstas presentan variaciones referentes a su origen.

Disecamos la cavidad abdominal de 89 cadáveres adultos de ambos sexos, de los cuales 69 fueron fijados en solución de formalina a 10\%, y 20 no fijados. Los cadáveres fijados fueron disecados en los laboratorios de Anatomía de la Universidad Federal de São Paulo-UNIFESP, en la Universidad de Santo Amaro-UNISA, y en la Universidad Lusíadas de Santos, UNILUS. Los cadáveres no fijados fueron disecados en los Servicios de Verificación de Óbitos de la capital (USP y UNIFESP), Brasil. Se verificó la emisión de arterias frénicas inferiores a partir del tronco celíaco y el lugar de origen de éstas.

Los resultados obtenidos indicaron la presencia de arterias frénicas inferiores en 31 (34.83\%) de los 89 cadáveres. En los otros $58(65.17 \%)$ el tronco celíaco no emitió tal ramo. También se verificó en $19(21.35 \%)$ de los 89 cadáveres, la arteria frénica inferior con origen en el contorno izquierdo del tronco celíaco, en $5(5.62 \%)$ ésta presentaba su origen en el contorno derecho y en 7 ( $7.86 \%$ ) emitía dos arterias frénicas, mientras que 5 de éstas se originaban separadamente de cada lado del tronco celíaco y 2 (2.25\%) de un único tronco.

Estos resultados permiten considerar el origen de las arterias frénicas inferiores en el tronco celíaco como una variación anatómica.

PALABRAS CLAVE: Anatomía; Arteria frénica; Arteria celíaca; Variación anatómica.

\section{REFERENCES}

Anson, B. J. \& McVay, C.B. The topographical positions and the mutual relations of the visceral branches of the abdominal aorta. A study of 100 consecutive cadavers. Anat. Rec., 67:7-15, 1936.

Lipshutz, B. A composite study of the coeliac trunkartery. Am. Surg., 65:159-69, 1917.

Michels, N.A. The hepatic, cystic and retroduodenal arteries and their relations to the biliary ducts. Ann. Surg., 133:503-24, 1951.

Michels, N.A. Variational anatomy of the hepatic, cystic, and retroduodenal arteries. Am. Med. Assoc., 66:20-34, 1953a.

Michels, N. A. Collateral arterial pathways to the liver after ligation of the hepatic artery and removal of the celiac axis. Cancer, 6:708-24, 1953b.

Pick, J.W. \& Anson, B. J. Inferior phrenic artery. Anat. Rec., 78:413-25, 1940.

Siegel, S. Estatística não paramétrica(para as ciências do comportamento). MacGraw-Hill, SãoPaulo, 1976.
Correspondence to:

Prof. Dra. Selma Petrella

Rua Rio Grande, 180 Apto. 62

São Paulo - Vila Mariana

CEP 04018-000

São Paulo - SP, BRASIL

Email:petrellaselma@ig.com.6r

Received: 14-10-2005

Accepted: 28-03-2006 